University of Nebraska - Lincoln

DigitalCommons@University of Nebraska - Lincoln

October 2001

\title{
Mixed-Bloods, Mestizas, and Pintos: Race, Gender, and Claims to Whiteness in Helen Hunt Jackson's Ramona and María Amparo Ruiz de Burton's Who Would Have Thought It?
}

Margaret D. Jacobs

University of Nebraska - Lincoln, mjacobs3@unl.edu

Follow this and additional works at: https://digitalcommons.unl.edu/historyfacpub

Part of the History Commons

Jacobs, Margaret D., "Mixed-Bloods, Mestizas, and Pintos: Race, Gender, and Claims to Whiteness in Helen Hunt Jackson's Ramona and María Amparo Ruiz de Burton's Who Would Have Thought It?" (2001). Faculty Publications, Department of History. 30.

https://digitalcommons.unl.edu/historyfacpub/30

This Article is brought to you for free and open access by the History, Department of at DigitalCommons@University of Nebraska - Lincoln. It has been accepted for inclusion in Faculty Publications, Department of History by an authorized administrator of DigitalCommons@University of Nebraska - Lincoln. 


\section{Mixed-Bloods, Mestizas, AND PINTOS: RACE, GENDER, AND Claims to WHITENESS IN HELEN HUNT JACKSON'S RAMONA AND MARÍA AMPARO RUIZ DE BURTON'S WHO WOULD HaVe THOUght IT?}

\section{MARgARET D. JACOBS}

Since the 1980 s, a growing number of scholars in widely different fields have discredited race as a self-evident category of human social relations. Alongside the work of scientists who have found no genetic or biological basis for racial categorization, critical race theorist have looked to changes in legal definitions of race and citizenship to conclude that race is socially and culturally constructed. Historians have contributed to the field by analyzing the history of Whiteness and the so-called White race. Many groups considered "White" today were once deemed non-White; it was only through renouncing common cause with other similarly stigmatized "races" that certain Americans such as Irish and Jewish immigrants were able to attain White status and privilege. "Of course, "choosing" to become White has not been an option for some Americans whose skin color is not light enough to allow them to pass for White. But as George Frederickson argues, it is not from color alone that race is constructed. He asserts that "the essential element [in notions of race and racism] is that belief, however justified or rationalized, in the critical importance of differing lines of descent and the use of that belief to establish or validate social inecquality" (55).

The social construction of race played out in myriad spaces: in brightly lit courtrooms and dark bedrooms, in factories and fields, in movie theaters and swimming pools, in classrooms and offices, in fastmoving trains and plodding city buses. The realm of literature as well became a space in which various Americans sought to envision and enforce their notions of race. The literature of the American West offers a particularly rich bounty of competing constructions of race. Until recently it has been all too common in the ficlds of both western American literature and western history to study AngloAmericans' views of the West and its peoples. A growing number of scholars, however, have challenged the ethnocentrism and cultural 
hegemony of this approach.

Significantly, though, we are not the first to engage in such a critique of Anglo-Americans' portrayals of the West. Even as Easterners flooded bookstores and literary journals with their accounts of the West in the nineteenth century, an elite and well-educated Californiana, María Amparo Ruiz de Burton, penned her own challenge to such representations. In 1872, countering Anglo notions that Californios were a "half barbaric" race who were unfit to govern themselves, to hold property, or to occupy professional positions, Ruiz de Burton published Who Would Have Thought It?, a political satire dressed up as a romance novel. Although written twelve years before one of the most famous Anglo novels about nineteenth-century California, Helen Hunt Jackson's Ramona, Ruiz de Burton's novel nevertheless reads like a sharp retort and a satire of Jackson's view of California and the West.

A number of literary scholars have found much to compare between Jackson's Ramona and Ruiz de Burton's other novel, The Squatter and the Don. ${ }^{2}$ Both take place in nineteenth-century California and provide contrasting views of Californio and indigenous cultures. A comparison of Who Would Have Thought It? and Ramona, however, yields further crucial insights into how Ruiz de Burton critiqued Easterners' views of the West. Rather than situating this novel in the West, Ruiz de Burton locates it primarily in New England. This allows Ruiz de Burton to turn the tables on all the "Yankees" who wrote about the West. ${ }^{3}$ Further it enables her to explore and contest the meaning of race and gender in nineteenth-century America. While Jackson and many of her compatriots attempted to exclude Californios from the privileges of Whiteness, Ruiz de Burton countered Jackson and others by laying a claim to Whiteness. In each case, the authors embody their differing views of race in similar ways, employing evil stepmother characters, notions of the nineteenth-century ideal of true womanhood, the figure of a beautiful girl of mixed racial descent, and the specter of interracial marriage. Jackson holds out the possibility that her mixed-race heroine might achieve White status, but she forecloses this option by the end of her novel. Ruiz de Burton literally bleaches her supposedly mixedrace heroine until she far surpasses her Yankee adoptive family in Whiteness, civilization, and true womanhood.

What emerges from comparing these two books is the unstable nature of racial categories in the late nineteenth century and how conquered elites fought to shape the new racial order. Although their voices have been silenced and their writings exiled until very recently in the West's literary and cultural history, the recovery of Ruiz de 
Burton's novels reminds us that race has never been a fixed and stable system, but one constantly contested. Indeed, although Ruiz de Burton never sought to obliterate racial hierarchics but simply wished to reestablish a racial system that would secure her own elite social status, she prefigured late twentieth-century scholars' theories regarding the social construction of race.

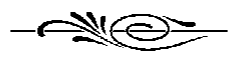

From 1848 through the late nineteenth century, the American conquest of California and the Southwest disrupted dominant racial hierarchics and categorizations, in both the East and the West. Two sets of racial hierarchies had pervaded mid-nineteenth California society: one dichotomous, the other multifarious. In one system, the gente de razón (Europeans and people of partially European heritage) separated themselves from the gente sin razón, or indigenous people. Such a system paralleled the civilized/savage dichotomy familiar to Yankees in the East. Yet, whereas Yankee conceptions of civilization required allegedly pure "White" blood, by the nineteenth century, the gente de razón encompassed a range of over fifty racial categories. Those who claimed pure Spanish blood (limpieza de sangre), however, reserved the titles of Californio and Californiana for themselves. As Rosaura Sánchez and others have pointed out, though, this assertion largely constituted a fiction. Interracial sex and marriage was common among Spanish, Indian, and mestizo populations in New Spain, and interracial relationships and marriages had already been occurring in Spain for centuries. ${ }^{4}$

To declare the Californio racial system a fiction is not to pretend that any other racial system was based on objective fact. The Yankee racial system of the nineteenth century was predicated on equally specious claims of pure blood and Whiteness. This system rested on two integrally linked dichotomies: the opposition between the civilized and the savage and between Black and White. Even "one drop" of Black blood, allegedly, made an individual Black. When trying to calculate the racial makeup of the peoples they encountered in the West, most Yankee travelers could countenance little outside the Black/White dichotomy. Some Yankees considered all of the nonindigenous population of California to be Whites. For example, Alfred Robinson divided the population of Alta California into White and Indian. But to other Yankees, all Spanish-speaking Mexicans were Black. Rufus Sage in 1858 remarked that Mexicans were as "black as veritable Negroes"” (qtd. in Paredes 19-20). 
Interestingly, some Yankees drew a color line between elite and poor Mexicans. Harriet Bunyard, traveling through Texas and southern New Mexico on her way to California in 1869, remarked on some Mexicans she passed, "They are very nice looking people, white as anybody. Us girls called into to see how the house looked. . . . Their house looked so nice and clean inside. They have black Mexicans for servants" (227). Seeing California in Black and White racial terms also led some Yankee travelers and settlers to imagine California as another American South. Nineteenth-century Yankee literature about California is replete with imagery of peaceful Indians toiling happily for their masters, as portrayed by Thomas Farnham, or, by contrast, of brutally exploited Indians slaving away for their cruel masters, as in the work of Richard Henry Dana. ${ }^{5}$

When they did veer away from fitting Californios into a Black/ White racial dichotomy, Yankees in California sometimes depicted the Californios as a separate Spanish race. Then the question of whether the Spanish were White became preeminent. Thomas Hart Benton declared in 1844, "We [the United States] are the first-she [Mexico] the second power of the NEW WORLD. We stand at the head of the anglo-Saxon-she at the head of the south-European race-but we all come from the same branch of the human family - the white branch"' (qtd. in Horsman 252). European ancestry, however, did not guarantee White status to Mexicans. In 1857, the historian Francis Parkman wrote that peoples in the American West could be "'separated into three divisions, arranged in order of their merits: white men, Indians, and Mexicans; to the latter of whom the honorable title of "whites" is by no means conceded"' (qtd. in Paredes 20). And Farnham characterized the "Spanish population of the Californias" as "In every way a poor apology of European extraction" (363). "That part of the population which by courtesy are called white," Farnham wrote, "[have a] complexion [which] is a light clear bronze; not white, as they themselves quite erroneously imagine; and, withal, not a very seemly color; not remarkably pure in any way; a lazy color" (358).

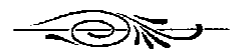

Helen Hunt Jackson inherited these sets of racial assumptions when she journeyed to the West in the 1880s. Jackson, a middle-class Yankee born in Massachusetts in 1830, began her literary career after her first husband and two sons died. At first she wrote short stories, 
travel sketches, children's books, essays, and poems, but in 1879 , after she had become incensed at the treatment of Native Americans, she began to use her literary abilities to call attention to their plight. After the publication of A Century of Dishonor (1881), which indicted federal Indian policy, Jackson obtained a position in 1883 as an investigator of conditions of the Mission Indians in Southern California. Appalled at the atrocities the Mission Indians had endured, Jackson determined to publicize their difficulties. Hoping to emulate Harriet Beecher Stowe's literary and reforming success with Uncle Tom's Cabin, Jackson turned to the genre of the novel, publishing Ramona in 1884.6 Yet, if Jackson intended solely to raise American consciousness about the dilemma of Mission Irdians, we must wonder why she made her main character a woman of mixed racial heritage. Why wouldn't it be just as effective for Jackson's purposes to tell the story of a young Mission Indian couple and their trials with Yankee settlers and state officials? More is at work in Ramona than a simple desire to arouse sympathy for the Mission Indians; the book also explores and ultimately affirms Yankee racial categories.

Ramona had been born to a Scottish shipping line owner, Angus Phail, and his Indian consort. Soon after her birth, Angus had brought his baby girl to Señora Ramona Ortegna, his one-time lover who had left him for another man twenty-five years before. Angus asks Señora Ortegna to adopt the baby, whom he has named Ramona after his one true love, and having had no children of her own, the Señora gladly accepts. When Angus dies, he bequeaths a set of jewels to his daughter, to be held in trust by Señora Ortegna. A few years later, as Señora Ortegna herself is about to die, she asks her sister, Señora Moreno, to raise Ramona. Despite Señora Moreno's dislike of "mongrel blood," she agrees to take Ramona. Thus the "mixed-blood" girl Ramona grows up in an elite Californio household with Señora Moreno, her son Felipe, and their retinue of servants.

Loved by all in the hacienda except Señora Moreno, Ramona lives as a Cinderella under the menacing figure of the Señora. When Ramona falls in love with and wishes to marry Alessandro, a Mission Indian man employed by the Moreno household, the Señora disowns her. Ramona and Alessandro, banished from the hacienda, return to his village only to find that it had been razed by Yankee settlers. When they try to move to another Indian village, Yankee squatters take over their land. Alessandro goes mad and is murdered by a brutish Yankee settler. Felipe brings Ramona back to the hacienda, and they eventually marry. Now finding California inhospitable to Californios as well as to Indians, the couple moves to Mexico. 
Through the character of Ramona, Jackson dramatizes two competing visions of race in late nineteenth-century America. At certain points in the book, race appears to be a matter of blood. When Señora Moreno discovers that Ramona has fallen in love with Alessandro, she declares that "base begotten, base born, she has but carried out the instincts of her nature" (125). Confronting Ramona, Señora Moreno attacks her, "I told my sister, when she took you, the Indian blood in your veins would show some day; and now it has come true"" (132). Other characters also identify race in terms of blood. Felipe, when challenging his mother's opposition to the marriage of Alessandro and Ramona, argues, "I don't see anything disgraceful in it, nor anything wrong, nor anything but what was perfectly natural. . . . [Y]ou know [Ramona] is half Indian" (143). Alessandro, though admiring Ramona from afar, never dares to imagine her as his bride until he learns that she "has Indian blood in her veins" (97). Throughout the book, though raised as a Spanish noblewoman, Ramona cannot escape the supposedly innate qualities that Jackson associates with Indianness. She likes sleeping outdoors, easily adopts Indian women's techniques for carrying heavy loads, and is inexplicably drawn to Alessandro. As John Morán González comments, "[T]he danger of racial reversion is always present in [Ramona's] mestiza blood" ("In the Wake" 124).

Yet if it was a matter of blood alone, the story would end here. Ramona and Alessandro would marry, with the blessing of Señora Moreno and Felipe. Instead, the Señora is incensed; she informs Ramona that she cannot marry an Indian although her mother was "a low, common Indian" (132). Ramona confronts the Señora, "Was it because I was an Indian that you have always hated me?"” The Señora retorts, "You are not an Indian"" (132). Explaining her position to Felipe, Señora Moreno asserts, "'[I]t would not be right for us to let Ramona do anything which we would not let her do if she were really of our own blood" (145). In these confrontations, race becomes a matter of environment, in some sense, a social construction.

What can we make of these seemingly contradictory stances regarding race that are embodied in the figure of Ramona and in her desire to marry Alessandro? How can Jackson represent race as both an inescapable biological fact and a mutable social construction at one and the same time? Perhaps Jackson and her characters are merely representative of her time. Certainly both sentiments coexisted in late nineteenth-century America. Jackson travelled in reform circles, associating with Yankee reformers who believed wholeheartedly that through a change in environment and education, Indians could be absorbed into the White race. 
Yet social Darwinists in the late nineteenth century regarded race as a biologically determined "fact of life."

Another explanation for the complicated view of race in Ramona may be its romanticization of the Indian. One of the most admirable characters in Jackson's book is Alessandro, the "full-blooded" Mission Indian. Jackson portrays Alessandro as "simple-minded" and "unlearned" (48) and declares that if he were civilized, he "would have been capable of weighing, analyzing, and reflecting" (53). Yet he is a veritable noble savage: good-hearted, strong, manly, close to nature, hardworking, and possessing a beautiful, haunting voice. As a pure, unadulterated Indian, Alessandro is able to respond to a change in his environment, brought by the Catholic missionaries whom Jackson lionizes. His family has adopted Christianity and made beneficial adaptations to new European social norms.

Ramona, of course, is the other most admirable character in Jackson's book, as is shown in the way she epitomizes the nineteenthcentury true woman. According to many scholars of women's history, an ideology of true womanhood developed coincidentally with the rise of the middle class in New England in the nineteenth century. This ideology upheld piety, sexual purity, domesticity, and submissiveness as the ideals all women should strive to realize in their lives. Intensely pious and simultaneously domestic, Ramona lovingly mends and washes the torn and dirtied altar cloth in preparation for the arrival of Father Salvierderra at the Moreno hacienda. Ramona also represents the sexual purity extolled by the cult of true womanhood. Having been schooled in a convent, she is innocent of the ways of love, courtship, and marriage. She does know, however, that the aggressive manner in which the Mexican servant Margarita pursues Alessandro is improper behavior. She, in contrast to Margarita, does not behave immorally with Alessandro. It is only after they have agreed to marry that the couple finally embraces.

It is in the contrast between Ramona and Margarita and between Ramona and the Moreno family that Jackson suggests that some mixes of blood could be integrated into the Yankee racial order, but others could not. A girl of Scottish and Indian descent-a "mixed blood"could possess the sexual purity associated with true womanhood and thus should be fully admitted to White society. In contrast, mestiza women, at least those of the lower classes, as represented by Margarita, lack the quality of sexual purity necessary for admission to the cult of true womanhood, and thus to the status of Whiteness. It is not the mix- 
ing of blood per se that Jackson's book condemns; it is the mixings of certain kinds of blood. Northern European and Indian produce a good mix. By contrast, Spanish and Indian produce something much less desirable.

Jackson's portrayal of Señora Moreno and Felipe, in fact, demonstrates that the mestizaje of Spanish and Indian ancestry has resulted in a "half barbaric" race (11). Jackson repeatedly subscribes to dominant contemporary stereotypes of the Californios, as for example when she describes Señora Moreno in her first chapter as appearing "indolent, like her race" (2). The Californios, whether of supposedly "pure" Spanish blood or of a mixture of Indian and Spanish blood, come across in Jackson's novel as a "race" of wicked, domineering women and weak, effeminate men who have unfairly exploited the Indians of California. As a historian of American Indians, I cannot disagree with Jackson's indictment of the Californios' exploitation of Indian labor and their sense of racial superiority. But Jackson's negative portrayal of the Californios suggests that she herself harbored a clear sense of racial supremacy over them. Jackson depicts Señora Moreno unrelentingly as a cruel vindictive woman who has overstepped the proper bounds of womanhood. Rather than allowing her son to rightfully rule his own hacienda, the Señora maneuvers and manipulates to effectively control everyone in her household.

Felipe, by turns, is not a real man like Alessandro because he proves incapable of standing up to his mother and succumbs easily to disease. As the novel opens, Felipe is ill and so sheep-shearing must be postponed. Once sheep-shearing finally begins, Felipe takes ill again as he packs fleeces on a high beam in the shed. Alessandro must rescue him. Another Mexican worker on the hacienda, Juan Canito, takes over Felipe's job; he, too, proves his incompetence by falling from the beam and breaking his leg. With sheep still to shear, the Señora finally hires Alessandro to take over, temporarily, as head shepherd. "There were many things that Felipe knew, of which Alessandro was profoundly ignorant," Jackson tells us; "but there were others in which Alessandro could have taught Felipe; and when it came to the things of the soul, and of honor, Alessandro's plane was the higher of the two" (74). Witnessing Alessandro's great generosity, Ramona exclaims to Felipe, "'I think they are better than we are, Felipe!" (78). Indeed, it appears that Jackson also believed that Indians were better than the mestizo Californios. In this complicated view of race, Jackson intimates that Indians and "mixed-blood" people of certain acceptable blendings could 
become White through changes in environment and education. But the Californios, Jackson suggests, would never be admitted within the bounds of Whiteness because something had gone awry with their "race." This particular racial mixture has emasculated men and improperly emboldened women.

For their part, the Californios objected to Jackson's and other Yankees' racial classifications. They had quickly discovered the value of Whiteness in the new racial climate after conquest. In the California constitution of 1849 , for example, only "White Mexicans" could vote. Texas, Arizona, and New Mexico used similar racial qualifications to deny suffrage to "Mexican Indians" or any people of Mexican descent living in the Southwest. It was left to each local jurisdiction to determine who was or was not White. Thus, those Californios who claimed to be White may have been acting out of two powerful impulses: to reassert the old order in which they held an elite status and to avoid the plight of non-Whites in the new racial order of the Yankees. ${ }^{\text {? }}$

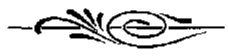

María Amparo Ruiz de Burton, a woman of self-proclaimed Spanish descent who was born and raised in Baja California, shared this desire to be classified as White. ${ }^{8}$ In 1848 , she and her mother moved to Monterey in Alta California, and one year later, at age seventeen, Amparo Ruiz married Captain Henry Burton, a twenty-eight-year-old graduate of West Point and a native of Connecticut, who had led a command of soldiers in the recent U.S.-Mexican War. The newlyweds settled first in Monterey and then moved to San Diego in 1852. In 1854, they homesteaded on Rancho Jamul, a land grant that had once belonged to Pío Pico. In 1858, the U.S. Land Commission, an entity set up by the Land Law of 1851 to determine the validity of large Spanish-Mexican land grants, invalidated Pico's land grant. Squatters began to settle on parts of the ranch.

In 1859, Ruiz de Burton, her husband, and their two children moved to the East. Captain Burton served in the Union Army during the Civil War, where he became a brigadier general and contracted malarial fever, which led to his death in 1869. In 1870, Ruiz de Burton returned with her children to San Diego and Rancho Jamul, and in 1872, she anonymously published a novel (in English) regarding her nearly ten years in the East: Who Would Have Thought It? After persistent court battles, Ruiz de Burton finally succeeded in validating the title to Rancho Jamul in 1875 . Despite her victory, however, she lost 
much of her land to one hundred and sixty squatters and creditors who filed against her estate in the 1880s. On top of this, Ruiz de Burton fought to retain her tract of land in Baja California against the interests of an international land developing firm. Her second novel, The Squatter and the Don, published this time under a pen name (C. Loyal) in 1885 , attempted to bring her plight over land litigation to the public light in the palatable form of the romance novel. ${ }^{9}$

Given her experiences, Ruiz de Burton might have despised her American conquerors. She certainly did use her novels to express her disillusionment with and critique of U.S. imperialism and expansionism. ${ }^{10}$ Furthermore, a common theme of both her novels is the hypocrisy of Yankees, who preached democratic ideals while simultaneously dispossessing the Californios of their land and spreading racial scorn against them. Despite her pointed critique of the United States and its attempts to disempower and darken the Californios, however, Ruiz de Burton does not despise her conquerors. Instead she seems to have felt as Don Mariano in The Squatter and the Don, who, when asked why he did not hate Americans, proclaimed, "Hate you? No, indeed! Never! ... Instead of hate, I feel great attraction toward the American people"" (165).

Indeed, Ruiz de Burton seemed only to want to be treated as a fullfledged American, and in the nineteenth century, if not now, that meant she needed to be White. Yet, in order to become White, Ruiz de Burton had to dismantle the sets of racial ideas and categories that had been circulated by Yankee writers. She attempted to do so, with great wit, in Who Would Have Thought It? As the novel opens, we are introduced to Lola, the main character, who appears to be a dark Mexican or Indian. She has come to live with a New England family, the Norvals, after Mr. Norval, on a four-year collecting trip to the Southwest, rescued her from captivity among the Mojave Indians. Mr. Norval learned that Lola's mother, a woman of "pure" Spanish blood, had been kidnapped in 1846 by the Apaches and sold to the Mojaves. Five months after her capture she gave birth to Lola. But these distinctions are lost on the other members of the Norval household. Upon first seeing Lola, the youngest Norval daughter exclaims, "Goodness! what a specimen! A nigger girl!"” (16). A gossipy busybody in the novel, Mrs. Cackle, proclaims, "To me they are all alike-Indians, Mexicans, or Californiansthey are all horrid"" (11). Mrs. Norval concurs, equating Lola with a baboon and sending her to eat and sleep with the servants. Clearly, Ruiz de Burton chafed at Yankees' inabilities to properly distinguish between Californio racial categories. 
But Ruiz de Burton employs an intriguing plot device to inform both the Norval household and her readers of the actual racial hierarchy. As time goes on, white spots appear on Lola's dark skin, a development that leads the Yankee townspeople to label her a member of the Pinto tribe of Indians. When she returns, after being educated at a convent, she is almost completely White. Lola falls in love with the Norvals' son, Julian, and when she finally confesses her love to him, she tells him that her skin "'was only stained by the Indians"” and that she "'hated to think that [Julian] might suppose [she] was Indian or black"" (100). Much later in the novel, the Norval sisters and a friend are discussing Lola's racial status (in front of her). Mattie Norval, the good sister, upbraids her sister for being jealous of Lola's good looks. "'Talk of Spanish women being dark! Can anything be whiter than Lola's neck and shoulders?"' (232). Realizing that, like Jackson, many Yankees considered neither Californios nor Spaniards to be White, Ruiz de Burton made explicit that Lola and other

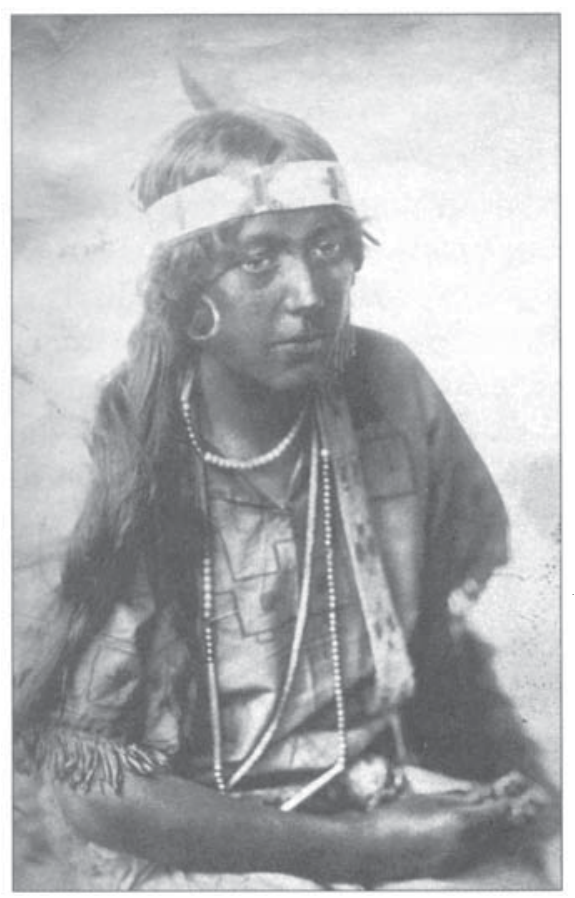
elite Mexican and California women deserved to be considered White by virtue of their color. In The Squatter and the Don, Ruiz de Burton makes a more direct plea for considering elite Mexicans as White. A Yankee newcomer is astonished that the elite Alamar men, Don Mariano and his sons, "look like Englishmen'” (85).

Ruiz de Burton also lays claim to Whiteness based on an analogy she draws between Californios and recently defeated Southerners, a parallel that González, Luis-Brown, and Aranda have all noted. In The Squatter and the Don, Yankee

Minerva Teichert in Indian Dress. 1916. Courtesy of the Museum of Church History and Art, Salt Lake City. Encouraged to pursue her artistic talents, Teichert left Idaho to study art in Chicago and New York. In New York, she supported herself by participating in a Wild West troupe as a trick rider and an Indian dancer. 
men who are moving from Northern California to squat on Californio land in San Diego load their wagon with "trunks and packages and carpet-bags" (69). The good American family, the Mechlins, have a Black servant, who, like the Indians who labor for the Alamar families, is happy, content, and devoted to the "White" family. Among the Anglo women in the novel, Mrs. Darrell, a refined woman of the South, is a woman of principle. At the end of the book, Ruiz de Burton makes even more explicit the connections between the defeated South and conquered California. The Texas-Pacific Railroad, foiled by railroad monopoly interests in the northern part of California, would not only have enriched San Diego, but would have "help[cd] the exhausted South to get back its strength and vitality" (274). Instead, due to the machinations of Leland Stanford and Henry Huntington, a "blight [had] spread over Southern California, and over the entire Southern States" (343). Ruiz de Burton ended this book by hoping "for a Redeemer who will emancipate the white slaves of California" (344). By using the term "Redeemer," Ruiz de Burton may again have meant to strike a parallel with the South, whose Democratic Party had "redeemed" its legislatures from the supposedly nefarious clutches of Black freedmen and northern Carpetbaggers.

While striking common cause between Californios and elite White Southerners, Ruiz de Burton uses Who Would Have Thought It? to critique Northerners. Nearly all of the New Englanders whom Ruiz de Burton describes in this novel are self-righteous hypocrites who preach against slavery in the South, but treat Lola as a "nigger." Curiously, though her novel is set during the Civil War, Ruiz de Burton never discusses the plantation economy and slavery at all, suggesting that she aligned herself with White Southerners. José Aranda has uncovered even more direct evidence that Ruiz de Burton sympathized with White Southerners. When Ruiz de Burton's husband, by then a general, took command of Regiment Headquarters in Fort Monroe, Virginia, in 1865 , his primary duty was to guard prisoner-of-war Jefferson Davis, the president of the Confederacy. Ruiz de Burton and her children lived at Fort Monroe, and she struck up a friendship with Varina Davis, Jefferson Davis's wife. The Davises expressed gratitude to the Burtons for their sympathetic treatment. Most telling, in a letter to a family friend, Varina Davis wrote that Mrs. Burton "'is a sympathetic warmhearted talented Mexican woman who is very angry with the Yankees about Mexican affairs, and we get together quietly and abuse them" (qtd. in Aranda 562). Thus Ruiz de Burton seems to have felt a sense of affinity with wealthy women of the South, who, like elite 
Californianas, had once enjoyed a lavish agriculturally based, nearly feudalistic lifestyle made possible by a group of "savage" people whose appropriate station in life was to labor for their social betters. Now the Yankees had denied both White Southerners and Californios their privileges of race and class. By aligning California with the South, Ruiz de Burton hoped to associate Californios with elite White Southerners and to gain admission to the exclusive White American club.

Ruiz de Burton also asserts the rights of Californios to be White on the basis of gender. She suggests in Who Would Have Thought It? that the Eastern New England women who have labeled themselves "true women" are hypocrites. Not only does Mrs. Norval profess to be an abolitionist yet treat the darkened Lola as her inferior, she also claims to be a chaste true woman, yet easily succumbs to the Reverend Hackwell's advances once her husband is lost in Africa. After learning of Lola's great riches, Hackwell plots to obtain her wealth by seducing Mrs. Norval, who fails to live up to the ideal of sexual purity:

Without saying a word, [Hackwell] put his arms around her, and gave her a long, very long, kiss. She was so surprised at first that she could not speak, and then she felt so weak in his arms, so powerless to resist, that she did not resist. The stately lady, paragon of propriety, was as morally weak as-as-what?

It is not easy to find a fit simile for a matron who, from a chaste Lucretia, suddenly turns into a Clytemnestra. (123-24)

Even though she doesn't really know if her husband has died in Africa, Mrs. Norval becomes engaged to and clandestinely marries Hackwell because "that one passion-her love for Hackwell — was beyond her mastery, ... . she forgot her dying son, and she did not mourn for her lost husband, who had been so good and generous to her. All she now thought of and longed for was to see Hackwell, to be near him" (135-36).

Ruiz de Burton not only points out Mrs. Norval's transgression of the sexual norms of true womanhood, but she also uses the occasion to further impugn Mrs. Norval's gross hypocrisy. Mrs. Norval, in fact, "had so far degenerated" that when Hackwell caressed her, "[s] he felt a thrill through her entire frame, just as might have felt one of those creatures-whom she so abhorred-who go to parties in low necks and short sleeves. . . She, a strict hater of popery, a pious, proper churchwoman, felt just the same." Hackwell, "her spiritual adviser, the man trusted by their congregation and held in reverence," possessed "the power thus to thrill her whole being and set her heart throbbing in such unmatronly, unpresbyterian tumult" (173). 
By contrast, it is the elite Hispanic women whom Mrs. Norval so disdains, with their Spanish blood, who carry the genuine mantle of true womanhood. It is both Lola and her mother, Doña Theresa Medina, who exude the qualities of true womanhood. ${ }^{11}$ Doña Theresa, though violated by "savages," did not consent to her degradation. As her husband and father discussed her fate, her portrait "smilcd on them as if saying, '. . . I was always pure, for my soul did not sin, although I was insulted by a savage. I was a martyr; now an angel" (202). Californianas in The Squatter and the Don are also impeccably virtuous, further examples of how Spanish women wholly deserve the crown of true womanhood.

Additionally, Ruiz de Burton is fond of reminding her readers that under Spanish colonial and Mexican law, women retained their property rights after marriage and did not fall under coverture-the law whereby English women and their descendants in North America did not have an independent legal or economic identity apart from their fathers or husbands. ${ }^{12}$ She uses the seemingly lower status of women within Yankee society to further bolster her claims of Whiteness. In The Squatter and the Don, she describes a scene among the Yankee squatters in which "[t]he heads of families all came [to the meeting] - the male heads, be it understood-as the squatters did not make any pretense to regard female opinion with any more respect than other men" (84). And in Who Would Have Thought It?, she writes in her best satirical style, "It was the anniversary of some great day in New England . . - - some great day in which the Pilgrim fathers had done one of their wonderful deeds. They had either embarked, or landed, or burnt a witch, or whipped a woman at the pillory, on just such a day" (62).

In a subplot in the book, Ruiz de Burton also reveals the poor treatment Yankee women receive at the hands of their government. Lavinia Sprig, Mrs. Norval's sister, goes to Washington, D.C., to tend wounded soldiers. While there, she learns that her brother Isaac has been imprisoned in a Confederate prison camp. She visits the Secretary of War in an effort to get her brother out of the camp and is treated rudely by both the secretary and his young male attendant. Lavinia thus is led to reflect that "no matter how much a woman, in her unostentatious sphere, may do, and help to do, ... . after all she is but an insignificant creature" (106). When she goes to visit a Congressman whom she knows, he mutters under his breath, "Women are so foolish! . . Bah! and they want to vote! Ridiculous!" (110). Another elected official, the Honorable Mr. Blower, dismisses her by declaring, "[I]t is not to be expected that 
ladies would exactly appreciate [the policies of war], they being beyond their sphere of thought" (115). Lavinia "never could see how it was that after men had been trying for so many years to govern the world, they had not yet been wise enough to settle their difficulties without killing and mutilating each other" (115). Lavinia "was no advocate of 'woman's rights," writes Ruiz de Burton. "She did not understand the subject even, but she smiled sadly, thinking how little woman was appreciated, how unjustly underrated" (129).

In these sections of the book, Ruiz de Burton accomplishes several purposes. She intimates her own struggles as a woman who fought against the U.S. government, and she also critiques the patriarchal attitudes present in Yankee society. Combined with her portrayal of the hypocritical Mrs. Norval, Ruiz de Burton paints a picture of a Yankee society that neither accords women proper respect and rights nor cultivates the true womanhood ideal. By contrast, Ruiz de Burton's Californianas fulfill the ideal of true womanhood and also enjoy greater rights than Yankee women. And thus, to Ruiz de Burton, the Californios deserve to be classified as White.

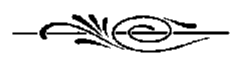

Ruiz de Burton published Who Would Have Thought It? in 1872, more than a decade before Jackson's Ramona. Yet the two novels create several analogous characters: just as Señora Moreno plays the evil adoptive mother to Ramona, Mrs. Norval serves a similar function to Lola. And Ramona and Lola both are supposedly mixed-race girls from the West. Such parallels seem to have been purely coincidental as there is no evidence that Jackson knew of Ruiz de Burton nor that she read her work. But what can we make of these parallel characters? The fictive mothers, in each case, represent the gatekeepers of their respective dominant societies: Mrs. Norval of Yankee middle-class society in New England, Señora Moreno of Californio elite society in California. Each author is critical of these elite women's poor treatment of the adoptive girls from other "races" who come to occupy their homes/societies. Charged with raising the girl as one of her own, neither mother ever fully accepts her adoptive daughter as equal with her own children. Instead, both Mrs. Norval and Señora Moreno and their respective societies view their adoptive children/conquered people as only fit to be servants. After Ramona shows her true colors, so to speak, Señora Moreno plans to send her back to the convent to be a servant. Mrs. Norval 
similarly plots to establish Lola as a servant in her neighbor's household.

The novels also include one very significantly similar plot detail: the presence of treasure that belongs to the mixed-race girl but that is appropriated by the cruel stepmother. Señora Moreno finally allows Ramona to marry Alessandro, but she refuses to let her keep her wealth. Ramona has thrown in her lot with the Indians and therefore is no longer allowed to keep her treasures. When Mr. Norval returns from his collecting trip with Lola in tow, he brings a load of boxes full of gold that Lola's mother entrusted to him as she died. He has promised to use the treasure to pay for her education. But Mrs. Norval schemes to obtain this gold for other purposes. In Ramona, Jackson intimates that elite Californios had robbed the Indians of their wealth. Ruiz de Burton, by contrast, suggests that it is elite Californios and other Mexicans in the West who rightfully possess such wealth, but whom greedy Yankees seek to plunder.

Through her portrayal of the bigoted Señora Moreno who withholds Ramona's rightful inheritance, Jackson implies that such elite Californios, falsely assuming their own superiority over Indians and other mixed-race people, do not deserve to be classified as White and thus should be excluded from full and equal participation in the (White) body politic of the United States. In Jackson's view, it is the Indians of California, and those who have mixed appropriately with northern Europcans, who can, under the tutelage of White Anglo-Saxons, become White. In contrast to Jackson, Ruiz de Burton establishes a different hierarchy. Rather than romanticizing Indians as noble savages, she depicts them as "horrid," "rascally" brutes who unfairly capture and violate good Spanish women $(36,34)$. Through her depiction of the prejudiced, greedy, and hypocritical Mrs. Norval, Ruiz de Burton proposes that it is actually Californios who most deserve to be counted as White and as full citizens. Through the marriage of Julian Norval and Lola at the end of the book, Ruiz de Burton asserts that an alliance between upstanding Yankees and Californios represents an amicable solution to conquest.

Ruiz de Burton's agenda, of making the Californios White, may seem out of date today. The Chicano movement has celebrated rather than denied its racial hybridity and its indigenous ancestry. Even in her day, not all elite people of Mexican descent sought to become White. For example, one Mexican American journalist in 1897 asserted that "instead of feeling shame [Mexican people] should be even more proud of carrying in their veins the blood of two illustrious as well as heroic 
races; since the Aztecs as much as the Spaniards, for their prowess, valor and lineage, have become justly worthy of the bronze of immortality of the imperishable crown of glory" (qtd. in Meyer 80). A portent of Corky Gonzales's "I Am Joaquin," this journalist's editorial reveals that certainly Ruiz de Burton's strategy to claim Whiteness was not the only perspective among the newly dispossessed Mexicans in North America. ${ }^{13}$

Clearly Ruiz de Burton, like many other Californios and Californianas, believed it more advantageous to throw in her lot with her conquerors and hope to be classified as White than to demote herself into the undifferentiated mass of "non-White" Mexicans and Indians who lost their citizenship rights along with their land. Ultimately, however, Ruiz de Burton's wishes never fully came to realization. Having European ancestry was not enough. Instead, Helen Hunt Jackson's ambiguous but exclusionary racial message gained greater currency. Still today, Americans of Spanish and Mexican descent occupy a liminal racial space, best exemplified by the census categories of "White" and "White-Hispanic." Such exclusion from the unearned and often unconscious privileges of Whiteness has meant that Spanish/Mexican Americans have been denied full citizenship in the United States. Nevertheless, Ruiz de Burton's clever challenge of the exclusivity of Whiteness opened the way to current struggles to dismantle Whiteness and other racial constructions altogether.

\section{NOTES}

I presented a version of this essay at the Western History Association conference in Portland, Oregon, in October 1999. I wish to acknowledge my copanelists John Nieto-Philips and Maria Raquel Casas for their insights, as well as the commentary of Albert Hurtado. I also wish to thank Rosamaria Tanghetti, who first introduced me to María Amparo Ruiz de Burton, and Tom Lynch, for his editorial assistance.

1. For examples, see Noel Ignatiev, How the Irish Became White (1995), Matthew Frye Jacobson, Whiteness of a Different Color (1998), David Roediger, The Wages of Whiteness (1999), Reginald Horsman, Race and Manifest Destiny (1981), Alexander Saxton, The Rise and Fall of the White Republic (1990), Tomás Almaguer, Racial Fault Lines (1994), and Neil Foley, The White Scourge (1997).

2. See, for example, David Luis-Brown and Anne E. Goldman.

3. Ruiz de Burton consistently uses the term "Yankees" to refer to Easterners from New England. I have adopted her term here rather than using the term "White," because it conveys a regional and political identity that also 
attempts to gain a monopoly on Whiteness. It permits me to move away from using a racial categorization such as "White" that merely perpetuates and reinforces race rather than contributes to its demise.

4. In addition to Sánchez, see R. Arturo Rosales, "'Fantasy Heritage' Reexamined: Race and Class in the Writings of the Bandini Family Authors and Other Californios, 1828-1965," in Recovering the U.S. Hispanic Literary Heritage, vol. 2, ed. Erlinda Gonzales-Berry and Chuck Tatum (1996); Martha Menchaca, "Chicano Indianism: A Historical Account of Racial Repression in the United States," in American Ethnologist 20.3 (Aug. 1993): 584-86; Manuel P. Servín, "California's Hispanic Heritage: A View into the Spanish Myth," in Between the Conquests: Readings in Early Chicano History, 2nd ed., ed. Michael R. Ornelas (1996); and Lisbeth Haas, Conquests and Historical Identities in Califomia, 1769-1936 (1995).

5. One particularly striking example of this tendency can be found in Elizabeth Hughes's The California of the Padres (1875). Bemoaning the industrialization of the post-Civil War era, she reminisces about life on the large California ranchos before the Anglo invasion: "Life was carried on there in a grand, old, patriarchal fashion" (8). Hughes's remark sounds hauntingly similar to much of the nostalgia for the Old South.

6. Biographical information on Helen Hunt Jackson can be found in the works of Mathes and in Dorris's introduction to Ramona.

7. See Martha Menchaca, "Chicano Indianism: A Historical Account of Racial Repression in the United States," in American Ethnologist 20.3 (Aug. 1993): 584-86; and David G. Gutierrez, Walls and Mirrors: Mexican Americans, Mexican Immigrants, and the Politics of Ethnicity (1995).

8. See Sánchez, Telling Identities 59, and González, "Romancing Hegemony" 27.

9. Biographical information on María Amparo Ruiz de Burton is available in the following sources: Sánchez and Pita, introduction to Who Would Have Thought It? and introduction to The Squatter and the Don; Crawford; and Haas 77-81.

10. For more on Ruiz de Burton's novels as anti-imperialist treatises, see Rosaura Sánchez, "Dismantling the Colossus," Beatrice Pita, "Engendering Critique," and José David Saldívar, "Nuestra America's Borders"-all three in José Marti's 'Our America': From National to Hemispheric Cultural Studies, ed. Jeffrey Belknap and Raúl Fernández (1998).

11. See also Goldman, "Who ever heard of a blue-eyed Mexican?"

12. For more on Spanish/Mexican women's property rights, see Haas 81-88 and Lothrop. Lothrop notes that "[b]y the latter part of the century the status a married woman had enjoyed under Spanish law was effectively undermined" (79).

13. In 1969, at the first National Chicano Youth Conference in Denver, Denver community organizer and former boxer Rodolfo "Corky" Gonzales expressed a sense of the dual Chicano identity in his poem "I Am Joaquin." 


\section{WORKS CITED}

Aranda, José F, Jr. "Contradictory Impulses: María Amparo Ruiz de Burton, Resistance Theory, and the Politics of Chicano/a Studies." American Literature 70.3 (September 1998): 551-79.

Bunyard, Harriet. "Diary of a Young Girl." Ho for Califomia! Women's Overland Diaries from the Huntington Library. Ed. Sandra L. Myres. San Marino: Huntington Library, 1980: 199-252.

Crawford, Kathleen. "María Amparo Ruiz Burton: The General's Lady." Journal of San Diego History 30.3 (Summer 1984): 198-211.

Dana, Richard Henry, Jr. Two Years before the Mast. New York: D. Appleton, 1899.

Dorris, Michael. Introduction to Ramona. By Helen Hunt Jackson. 1884. New York: Penguin Books, 1988: v-xviii.

Famham, Thomas J. Travels in Califormia and Scenes in the Pacific Ocean. New York: Saxton \& Miles, 1844.

Frederickson, George. "Reflections on the Comparative History and Sociology of Racism." In Racial Classification and History. Vol. 3 of Critical Race Theory: Essays on the Social Construction and Reproduction of "Race." Ed.

E. Nathaniel Gates. New York: Garland Publishing, 1997: 51-66.

Goldman, Anne E. "'I Think Our Romance Is Spoiled,' or, Crossing Genres: California History in Helen Hunt Jackson's Ramona and María Amparo Ruiz de Burton's The Squatter and the Don." Over the Edge: Remapping the American West. Ed. Valerie Matsumoto and Blake Allmendinger. Berkeley: University of California Press, 1999: 65-84.

. "'Who ever heard of a blue-eyed Mexican?': Satire and Sentimentality in María Amparo Ruiz de Burton's Who Would Have Thought It?" Recovering the U.S. Hispanic Literary Heritage. Vol. 2. Ed. Erlinda GonzalesBerry and Chuck Tatum. Houston: Arte Público Press, 1996. 59-78.

Gonzales, Rodolfo "Corky." "I Am Joaquin." Viva La Raza! Readings on Mexican Americans. Ed. Julian Nava. New York: D. Van Nostrand, 1973: 160-62.

González, John Morán. "In the Wake of Reconstruction: National Allegory and Narrative Form, 1877-1907." Ph.D. diss., Stanford University, 1997.

-. "Romancing Hegemony: Constructing Racialized Citizenship in María Amparo Ruiz de Burton's The Squatter and the Don." Recovering the U.S. Hispanic Literary Heritage. Vol. 2. Ed. Erlinda Gonzales-Berry and Chuck Tatum. Houston: Arte Público Press, 1996. 23-39.

Haas, Lisbeth. Conquests and Historical Identities in Califomia, 1769-1936. Berkeley: University of Califomia Press, 1995.

Horsman, Reginald. Race and Manifest Destiny: The Origins of American Racial Anglo-Saxonism. Cambridge: Harvard University Press, 1981.

Hughes, Elizabeth. The Califomia of the Padres; or, Footprints of Ancient Communism. San Francisco, Calif.: 1. N. Choynski, 1875. 
Jackson, Helen Hunt. Ramona. 1884. New York: Penguin Books, 1988.

Lothrop, Gloria Ricci. "Rancheras and the Land: Women and Property Rights in Hispanic California." Southern Califomia Quarterly (Spring 1994): $59-84$.

Luis-Brown, David. "'White Slaves' and the 'Arrogant Mestiza': Reconfiguring Whiteness in The Squatter and the Don and Ramona." American Literature 69.4 (Dec. 1997): 813-39.

Mathes, Valerie Sherer. Helen Hunt Jackson and Her Indian Reform Legacy. 1990. Norman: University of Oklahoma Press, 1997.

Mathes, Valerie Sherer, ed. The Indian Reform Letters of Helen Hunt Jackson, 1879-1885. Norman: University of Oklahoma Press, 1998.

Meyer, Doris L. "Early Mexican-American Responses to Negative Stereotyping." New Mexico Historical Review 53.1 (January 1978): 75-91.

Paredes, Raymund A. "The Mexican Image in American Travel Literature, 1831-1869." New Mexico Historical Review 52.1 (January 1977): 5-29.

Robinson, Alfred. Life in California: During a Residence of Several Years in That Territory. I846. New York: De Capo, 1969.

Ruiz de Burton, María Amparo. The Squatter and the Don. 1885. Ed. and intro. Rosaura Sánchez and Beatrice Pita. Houston: Arte Público Press, 1997.

. Who Would Have Thought It? 1872. Ed. and intro. Rosaura Sánchez and Beatrice Pita. Houston: Arte Público Press, 1995.

Sánchez, Rosaura. Telling Identities: The Califomio testimonios. Minneapolis: University of Minnesota Press, 1995.

Sánchez, Rosaura, and Beatrice Pita. Introduction to Who Would Have Thought It? By María Amparo Ruiz de Burton. 1872. Houston: Arte Público Press, 1995: vii-lxv. - Introduction to The Squatter and the Don. By Maria Amparo Ruiz de Burton. 1885. Houston: Arte Público Press, 1997: 7-49.

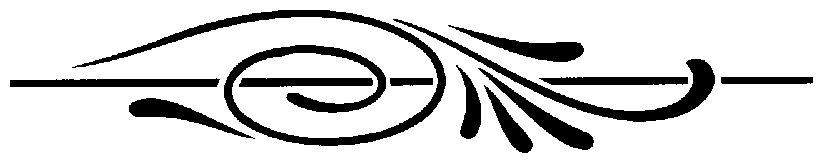

